\title{
Assessment of Therapeutic Ultrasound Effect On Cell Viability, Osmotic Integrity, And Dielectric Behavior
}

\author{
Moustafa Hussien Moustafa \\ Medial biophysics department, Medical research institute, Alexandria university, \\ Egypt.
}

\begin{abstract}
$\mathbf{U}^{\prime}$ LTRASOUND is relatively available, simple, and energy saving sound wave. Hence it became anemerging technology for many biomedical applications. Low energy (low power, low intensity $\left(>100 \mathrm{kHz}, 1 \mathrm{~W} / \mathrm{cm}^{2}\right)$ ultrasoundisusedformonitoringthecompositionand physicochemical properties. On the other hand, High energy(high power, high-intensity, $\leq 500$ $\mathrm{kHz}$ ) ultrasound may induce mechanical, physical, and chemical/biochemical changes through cavitation that is potentially compromising cell viability.The goal of this work to investigate the potential effect of using therapeutic ultrasound on the membrane viability and integrality of biological cell sample. Red blood cells (RBCs) were our choice to examine the cell viability under the therapeutic intensity range of $0.5-3 \mathrm{~W} / \mathrm{cm}^{2}$. Trypan blue dye exclusion test was to determine the integrity of the cellular membrane. Cell membrane osmotic fragility of (RBCs) was measured under series of saline solution osmotic pressure. The electrical signature of (RBCs) was correlated before and after ultrasound irradiation. The results showed no significant alteration in (RBCs) integrity and electrical behavior under the US irradiation intensity range. As a result, using the therapeutic US of intensity range of $0.5-3 \mathrm{~W} / \mathrm{cm}^{2}$, showed no significant harmful effect on RBCS integrity and viability under current experimental conditions.
\end{abstract}

Keywords: ultrasound, intensity, osmotic fragility, viability, dielectrics

\section{Introduction}

Physically "ultrasound "applies to all acoustic energy off requency above human hearing $(20,000$ hertz or 20 kilohertz). Typical diagnostic sonographic scanners operate in the frequency range of 2 to 18 megahertz, hundreds of times greater than the human hearing limit.Dolphins and bats are examples of animals that utilize backscattering sound ultrasound waves for navigation and hunting respectively. Utilize ultrasound for navigation (dolphins) or hunting (bats) using the information carried (Rebecca et $a l$ ).

Despite its discovery before $\mathrm{x}$-rays in late eighteenth (1883), ultrasound is much later involved in medical applications. The first application of ultrasound waves was recorded during World War I for detecting submarines. Ultrasound has the privilege of non-invasiveness, good visualization characteristics, and relatively easy management (Awad T.S. et al, wikipedia. org).
Medical Ultrasound can be mainly applied to; diagnostic imaging techniques, or therapeutic applications. Ultrasound has the privilege of being anon-invasive, non-ionizing module. It provides real-time imaging, easily portable, and cost-effective (Wikipedia.org). Sonography(ultrasonography) is widely used in medicine as diagnostic and therapeutic procedures, using ultrasound. Sonography is effective imaging module for soft tissues at a higher frequency (7$18 \mathrm{MHz}$ ), while deeper tissues operate at a lower frequency (1-6 MHz).Doppler ultrasound can be used to asses the blood flow and hemodynamics ( William et al).

The US has been used for therapeutic purposes such as physiotherapy, lithotripsy, kidney stone destruction, in tissue ablation in the tumor as highintensity focused ultrasound (HIFU).(HIFU), has also been applied as a drug delivery enhancer and thrombolysis. Ultrasonic manipulation of the suspended particle has been widely used in traditional chemical engineering and material 
sciences. Particles subjected to acoustic waves are influenced by acoustic radiation forces, which are particularly strong in standing wave fields. The particles can be gaseous, liquid, solid, or even biological cells.( Denggao et al)

For proper progress in using therapeutic ultrasound, a better understanding of ultrasound tissue interaction is urgent. Many studies indicated that the acoustic field caused no variation in particle integrity and cell viability in mammalian cells and erythrocytes (Zahra et al.)

The thermal effect could be a side effect for ultrasound exposure. This effect arises from the absorption of ultrasonic that also depends on tissue properties and beam configuration. The non-thermal effect of ultrasound could be acoustic radiation force, radiation torque, acoustic streaming, cavitations, and shock waves(William et $a l)$.

In the current work,we propose certain Assessment tests of therapeutic ultrasound effect (intensity range 1 to $3 \mathrm{~W} / \mathrm{cm}^{2}$ ) on RBCs viability, membrane osmotic integrity. The dielectric behavior (permittivity and conductivity) of the cells was investigated beyond ultrasonic irradiation.

\section{Material and Methods}

Subjects and RBCs

Twenty healthy male volunteers (age about 35y) were enrolled in this study. They were freely asked for written consent to be involved in the work according the institutionl ethical protocol. The working protocol was in-line with standard Medical Research Institute guidelines. All Precautions for contamination were obeyed during vein-puncture.

RBCs osmotic fragility test

RBCs integrity osmotic fragility test was performed (Arthur et al).Twenty micrometers of RBCswas added to two $\mathrm{ml}$ of saline concentrations from 0 to $0.9 \% \mathrm{NaCl}$, and leaft in 30 in dark at room temperature for 30 minutes. The resultant was centrifuged at 8000 r.p.m for 15 min. absorbance (A) of the supernatant for each concentration against $100 \%$ lysis (Tube marked 0 concentrations saline) at a wavelength of $540 \mathrm{~nm}$ using Jenway UV-visible spectrophotometer.The percentage of hemolysis was determined using Equation 1

$\%$ Hemolysis $=\left(\frac{\text { Optical density of sample }}{\text { Optical density of } 100 \% \text { lysis }}\right) \times 100$ Equation 1

The osmotic fragility curve $(\mathrm{NaCl}$ concentration on $\mathrm{X}$-axis and \% Hemolysis on Y-axis was plotted. The concentrations of $\mathrm{NaCL}$ at which 50\% hemolysis occur for control and test samples (median corpuscular fragility MCF) were determined from the curve.

\section{Dielectric measurements}

Dielectric measurements were made in the frequency range $42 \mathrm{KHz}$ to $5 \mathrm{MHz}$ using an LCR meter (Hioki, 3532, LCR Hitester,

TABLE 1: Demographic and blood indices characteristics for twenty healthy male volunteers.

\begin{tabular}{cc}
\hline Criteria & Value (mean $\pm \mathrm{SD})^{*}$ \\
\hline Age, year & $\mathbf{3 5} \pm \mathbf{5}$ \\
Weight, $\mathrm{kg}$ & $\mathbf{8 0} \pm \mathbf{7}$ \\
Haemoglobin, g/dl & $\mathbf{1 4} \pm \mathbf{2}$ \\
Red blood cells (RBCs), $10^{6} / 1$ & $\mathbf{4 . 8} \pm \mathbf{1}$ \\
Hematocrit $(\mathrm{HCT})$ & $\mathbf{4 1} \pm \mathbf{3}$ \\
Mean corpuscle volume(MCV) & $\mathbf{8 5} \pm \mathbf{2}$ \\
MCHC & $\mathbf{3 3} \pm \mathbf{5}$ \\
White blood cells, $10^{3} / 1$ & $\mathbf{6} \pm \mathbf{3}$ \\
Neutrophils, $\%$ & $\mathbf{5 5} \pm \mathbf{1 0}$ \\
Lymphocytes, $\%$ & $\mathbf{2 0} \pm \mathbf{1 2}$ \\
Platelets, $10^{9} / 1$ & $\mathbf{2 5 0} \pm \mathbf{5 0}$ \\
Fasting blood glucose, $\mathrm{mg} / \mathrm{dl}$ & $\mathbf{7 7} \pm \mathbf{5}$ \\
\hline
\end{tabular}

$*$ p-value $>0.05$, sample were measured duplicate then,

mean \& standard deviation (S.D.) were measures.

Egypt. J. Biophys. Biomed. Eng., Vol. 23 (2021) 
Japan). The (CNTs) sample was placed in a homemade measuring cell was designed as two cubic silver electrodes of area (A) 1x1 mm2 and $5 \mathrm{~mm}$ apart (d). Thecapacitance (C) and resistance $(\mathrm{R})$ was recorded over the frequency range at room temperature . Dielectric constant (relative permittivity) $\left(\varepsilon^{r}\right)$, and imaginary parts (dielectric $\operatorname{loss}\left(\varepsilon^{\circ}\right)$ was calculated usingEquation 2 , andEquation 3 respectively. The RBCs conductivity $(\sigma)$ was also calculated from the Equation 4 as a function of the frequency.The test was repeated three times to calculated the mean value.

$$
\varepsilon=\frac{C d}{\varepsilon^{*} A} \text { Equation } 2
$$

(Where, $\varepsilon^{\circ}$ free spacepermmitivity $\sim 8.854 \times 10^{-12}$ $\mathrm{C}^{2} \mathrm{~N}^{-1} \mathrm{~m}^{-2}$ )

$$
\begin{gathered}
\varepsilon=\frac{\varepsilon}{2 \pi \cdot f \cdot R \cdot C} \text { Equation } 3 \\
\sigma=2 \pi \cdot f \cdot \varepsilon \cdot \varepsilon^{\circ} \text { Equation } 4
\end{gathered}
$$

\section{Trypan blue viability test}

Trypan blue dyeexclusion test is based on the principle that living cells have intact cell membranes that exclude certain dyes, like trypan blue, Eosin, or propidium, whereas nonliving cells do not. When a cell suspension is mixed with the dye and then visually examined to determine whether cells take up or exclude the dye. The viable cell will have a clear cytoplasm while nonviable cell with blue cytoplasm.

The stainedRBCswere examined by using haemocytomerterunder light microscope, and the percent viable cell count was calculated relative to the whole count of the cells in the fieldper each intensity of the (TUS).

\section{Results}

The complete blood pictures are shown in Table 1 for all studysample. The mean hemoglobin concentration, and blood cell indices (HCT, MCV, and $\mathrm{MCHC}$ ) showed no significant changes.

The mean percentage of RBCshaemolysis (osmotic fragility) against $(\mathrm{NaCl})$ concentrations is shown in Figure 1. The RBCs membrane fragility of all ultrasound irradiated groups showed no significant differences with normal group.

The electrical relative permittivity $(\dot{\varepsilon})$ and electrical conductivity $(\sigma)$ are presented in Figure 2. the behavior is a regular dielectric relaxation of alpha and beta relaxation within the working frequencies at room temperature. Concerning the conductivity, there is an ordinary opposit manner. Our finding showed non significant shifting in permittivity relaxation curves of RBCs before and after TUS irradiation. The manner of conductivity is still within the acceptable regular response.

The percentages of viable cells are related with the corresponding TUS intensities shown in Figure 3. The curves points showed a good fitting expressed by the determination coefficient $\left(R^{2}\right)$ values of 0.6 . As we noticed there is no significanttoxic effective using the current(TUS) on the cellsmembrane viability.

\section{Discussion}

Maintain high cellular viabilitypotentialintere sttoresearchersinthefieldofUS-inducedintracellula rdrugdeliveryandultrasonicmanipulationofbiologi calcells. Here in the current work we carried out some experimental procedure topredict the effectof therapeutic ultrasound (intensity range 1 to $3 \mathrm{~W} /$ $\mathrm{cm}^{2}$ ) on red blood cell (RBCs) viability, membrane osmotic integrity. The dielectric behavior (permittivity and conductivity) of the cells was investigated beyond ultrasonic irradiation.

Normal mammalian (RBCs) membrane is selective permeable to fluid and nutrient to maintain thecell viability. As fluid diffuses more into the cell, it swells to assume these varied volumes until it reaches its "critical haemolytic volume. Beyond this volume the cell lyses or bursts to release its content into the surrounding.

The osmotic fragility test for human mammalian erythrocytes has been reported to be an indicative of cell viability and integrity. The Shiftingin RBCs osmotic fragility from normal response isused as an important diagnostic procedure in certain disease such as hereditary spherocytosis, betathalasaemia, sickle cell anaemia and autoimmune haemolyticanaemia (Grzegorz etal).

Trypan blue dye exclusion staining is one of the traditional methods foe assement of cell viability. This technique has been the standard methodology used in academic research laboratories and industrial biotechnology plants. The basic principle of the procedure rely on live cells have intact cell membranes that exclude trypan blue dyes, while non living ones accept the dyes (DyanKristine et al).

Our results indicated a regular dielectric behivourin alpha or beta relaxation region. As shown in figure 2, the dielectric constantdecreseas 
frequency increase. The cell dipoles may lining with the direction of the applied external field at low-frequency range. At higher frequencies , the dipoles are hardly to orient with the field. These finding were in line with earlier works on electrical properties of RBCs.On the other hand, electrical conductivity behaves in opposite manner. (Kristine et al)

\section{Conclusions}

The usage of therapeutic ultrasound of intensity $\left(0.5-3 \mathrm{~W} / \mathrm{cm}^{2}\right)$ provides a rapid, cost effective, and safe tool in dealing with human red blood cells. The cell viability was monitored by the trypan blue exclusion test showd non sigficant alteration in cell viability. The osmotic fragility test showed a significant normal membrane integrity under the working frequecies.There is slight significant shifting in dielectric screening in comparsion with control at the intensity of 3 $\mathrm{W} / \mathrm{cm} 2$ may be due to increasedacoustic radiation forces exerted upon the cell membrane.

\section{References}

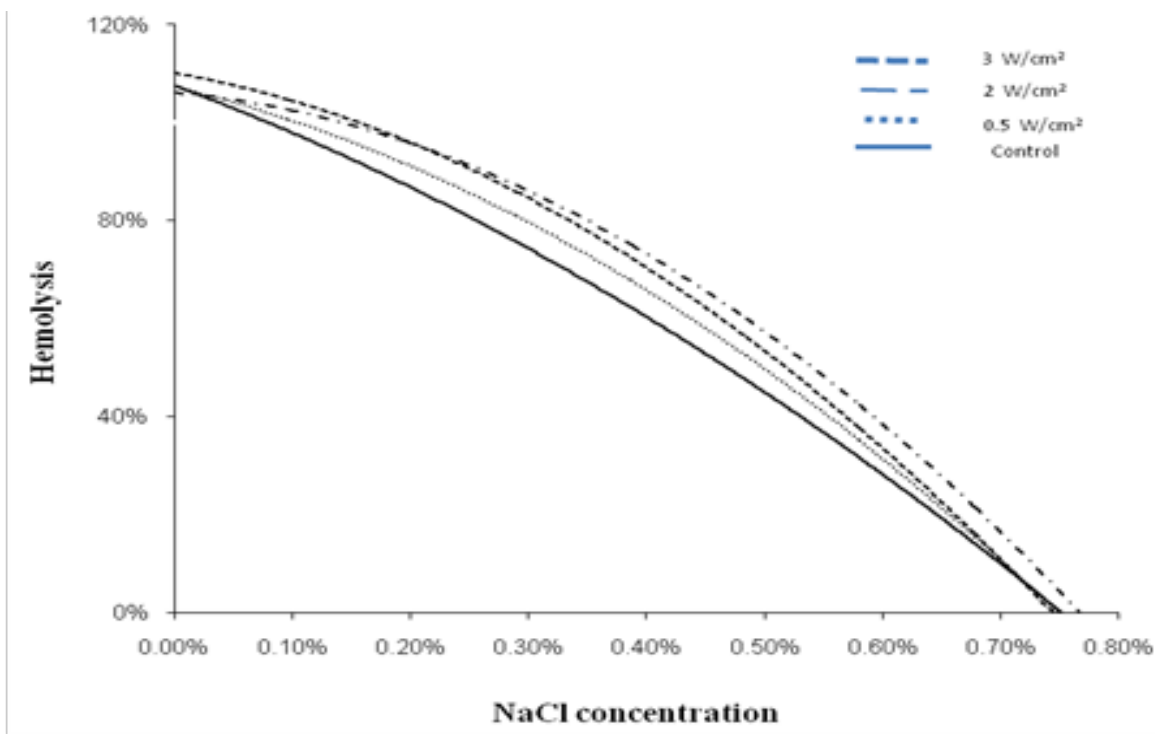

Fig.1: Percentage of RBCs hemolysis against serial saline concentration per each intensity of therapeutic ultrasound irradiation.

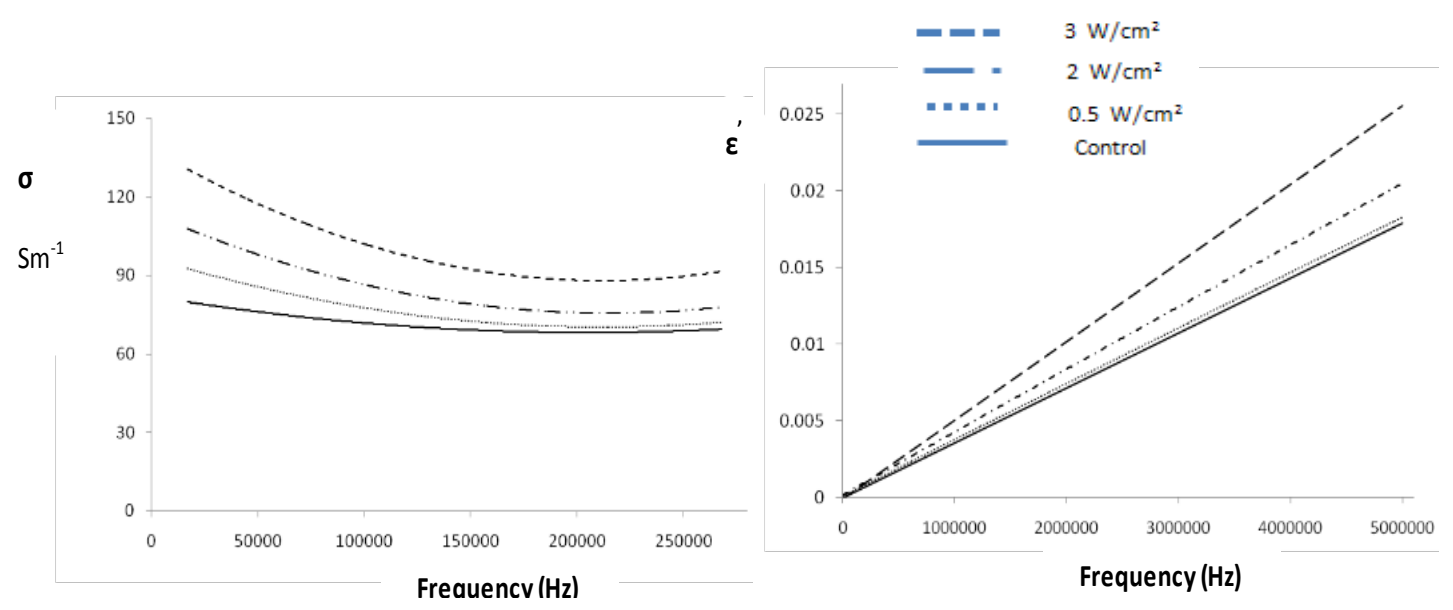

Fig.2: Dielectric spectrum of RBCs, relative permittivity (right), conductivity (left), comparing the dielectric behavior for control and TUS irradiated sample with different intensity.

Egypt. J. Biophys. Biomed. Eng., Vol. 23 (2021) 


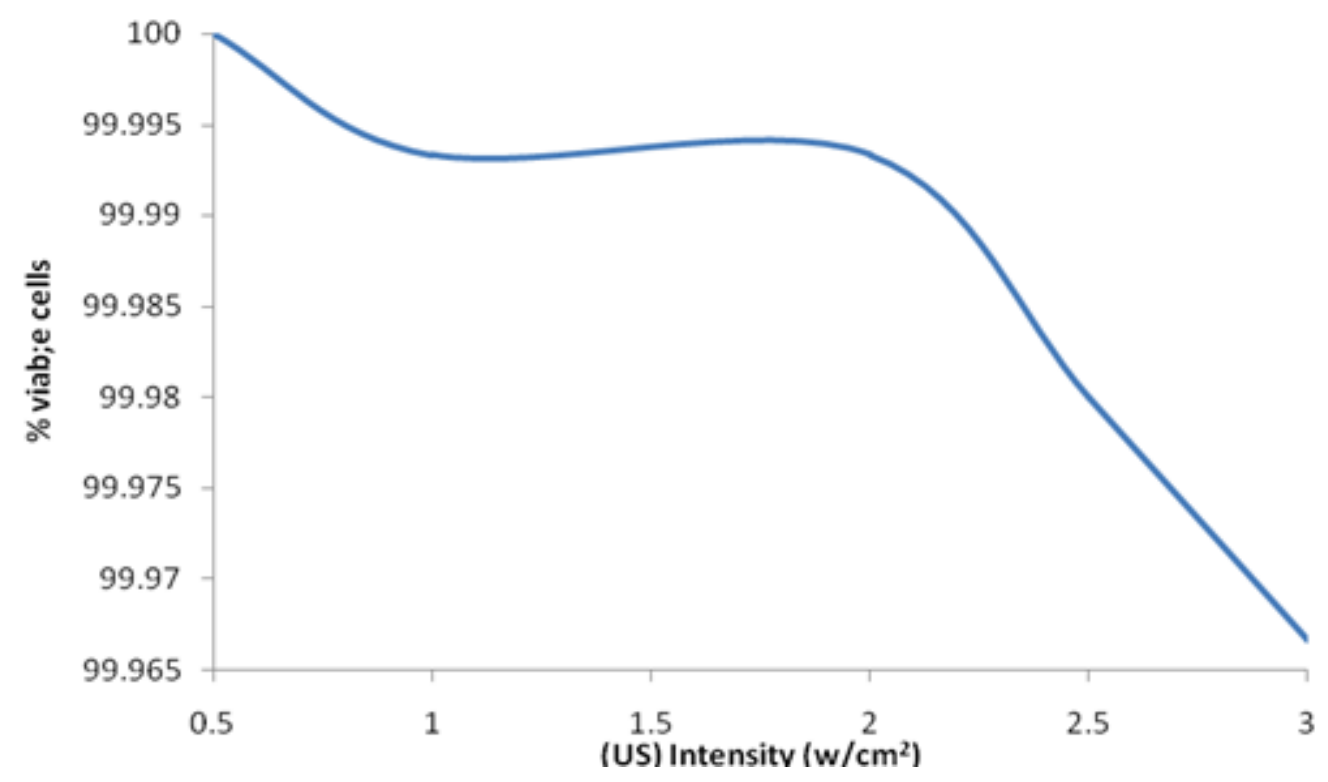

Fig. 3: between the percentage of viable RBCs. against corresponding irradiated ultrasound intensity. $\mathbf{R}^{2}$-Value are expressed showing the fitting between data.

Rebecca,Lorsung, M. Robert, Rosenblatt, B.GadiCohen, Joseph, Frank, A. and Scott Burks, R. Frontiers in Bioengineering and Biotechnology.8, 870 (2020).

“ht tps://en.wikipedia.org/w/index. php?title=Therapeutic_ultrasound\&oldid $=9934329$ 90"accesssed 15-1-2021.

Denggao H., Yuanhui, G., Shunlan W., Wei Z., Hui C., LinlinZ., Yang C., Shufang Z., and Jie C. Scientific RepoRtS.10,13690 (2020).

Scott ,Burks, R. Bailey ,M. R., Khokhlova, V. A., Sapozhnikov, O. A., Kargl, S. G., and Crum, L. A. Acoustical Physics, 49, 4( 2003).

Awad , T.S., Moharram,H.A., Shaltout. O.E., Asker D., Youssef, M.M. Food Research International, 48 (2012)410-427.

Aladin, C., Fahrudin S., Dzelaludin, J. AIM, 19,3(2011).

ITA, S.O., AKPOGOMEH, B.A. Journal of Medical Laboratory Science, 14,( 2005).

Jagannathan S., Berlyn R., Samir M. Biophysical Journal, 84(2003)

ZAHRA I., PAUL B.,DEAN C. Ultrasound in Med.\&Biol.43,6(2017).

Grzegorz B.,Andrzej S. American Journal of Hematology, (1989).

William D. ProgBiophys Mol Biol . 93(1-3) (2007).

Dyan N.A., Dario C., Junjun L., Peter G.,Paul A., Xunli Z., and Martyn H. Journal of Nanobiotechnology (2013).
Kristine S.L., Andre C.S. Methods In Molecular Biology.(2011)

Arthur K.,Parpart, Philip B., Lorenz, Ethel R. Parpart, John R. Gregg, and Aurin M. chase. J Clin Invest, 26,4(1947).

Lilliehorn, T., Simu, U., Nilsson, M., Almqvist, M., Stepinski, T., Laurell, T., Nilsson, J., Johansson, S. Ultrasonics. 43(2005).

Gherardini., L., Cousins, C.M, Hawkes, J.J., Spengler, J., Radel, S., Lawler, H., Devcic-Kuhar, B., Gröschl, M, Coakley, W.T., and McLoughlin A.J. Ultrasound in Medicine \& Biology. 31,2( 2005). 


\section{استبيان التأثير المحتمل لاستخدام الموجات فوق الصوتية العلاجية على حيوية

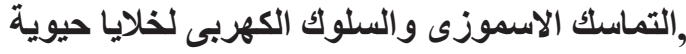 مصطفى حسين مصطفى قسم فيزياء حيوية طبية ـمعهد البحوث الطبية -جامعة الاسكندريه ـ مصر}

الهدف من هذه الدر اسه هو استبيان التأثير المحتمل لاستخدام الموجات فوق الصوتية العلاجية بثدة (فى حدود

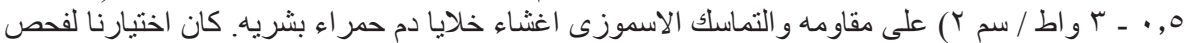

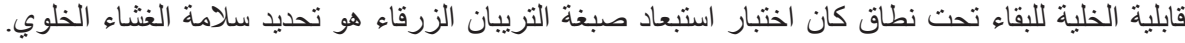

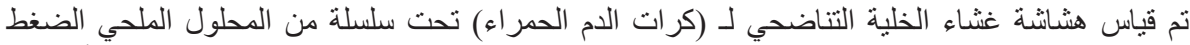

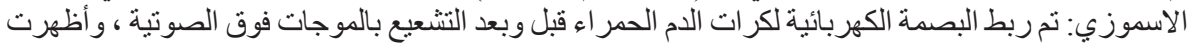

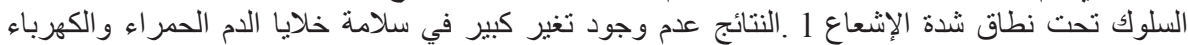

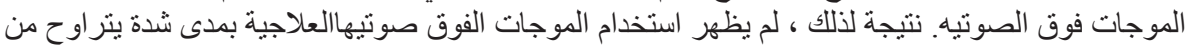
0.5 إلى 3 و اط / سم 2 أي تأثثر ضار كبير على سلامة كرات الدم الحمر اء وقابليتها للبقاء في ظل الظرات التروف التجرييية الحالية 